\title{
Psychological and socio-cultural adaptation of international journalism students in Russia: The role of communication skills in the adaptation process
}

\author{
Anna A. Gladkova \\ Faculty of Journalism, Lomonosov Moscow State University, Moscow, Russia \\ Corresponding author. E-mail: gladkova_a@list.ru
}

Background. The study of both Russian and international publications issued in the last twenty years revealed a significant gap in the number of studies examining adaptation (general living, psychological, socio-cultural, etc.) in general, i.e., without regard to specific characteristics of the audience, and those describing adaptation of a particular group of people (specific age, ethnic, professional groups, etc.).

Objective. The current paper aims to overcome this gap by offering a closer look at the adaptation processes of international journalism students at Russian universities, in particular, their psychological and socio-cultural types of adaptation. The question that interests us the most is how psychological and socio-cultural adaptation of international journalists to-be can be made easier and whether communication-oriented techniques can somehow facilitate this process.

Design. In this paper, we provide an overview of current research analyzing adaptation from different angles, which is essential for creating a context for further narrower studies.

Results. We discuss adaptation of journalism students in Russia, suggesting ways to make their adaptation in a host country easier and arguing that the development of communication skills can be important for successful adaptation to new living and learning conditions.

Conclusion. We argue that there is a need for more detailed, narrow-focused research discussing the specifics of adaptation of different groups of people to a new environment (since we believe different people tend to adapt to new conditions in different ways) as well as research outlining the role of communication competences in their adaptation processes.

Keywords: psychological and socio-cultural adaptation, international students, journalism, communication skills, communication competence 


\section{Introduction}

Today, Russia is seventh in the world in the total number of international students with 230 thousand international students or $3.8 \%$ of the total number of international students in the world (Arefyev \& Sheregi, 2014). The most popular study programs among full-time international students in Russia are engineering $(20.2 \%$ of the total number of international students), medicine (18.1\%) and management $(17.3 \%)$. The number of international students studying humanities in Russia - including journalism and mass communication studies - is lower but still relatively large at $11.5 \%$ (ibid). Among all international students in Russia, the biggest group of students currently come from Kazakhstan (28.8\% of all international students), Belorussia (9.4\%), Ukraine (8.5\%), and Turkmenistan (8.4\%). Countries like Azerbaijan, China, Tajikistan, Moldavia and India are also active in sending their students to Russia for higher education (Malykhin, 2015). Keeping this statistical data in mind, it seems clear that international students comprise an important group of the Russian student body and have their own specific needs. Coming to a new country to study or to conduct research makes international students face a number of challenges, including separation from their families and home environment, lack of Russian proficiency (most courses in Russia excluding short-term programs and dual degree programs with foreign universities are taught in Russian), and isolation from their cultural backgrounds. Scholars argue that these and other factors may cause psychological distress, which international students oftentimes experience in a new country. Berry (1997) and others noted that factors that may influence the amount of psychological distress and the way students cope with that stress can be grouped into three main categories: macrosocial (discrimination, degree of tolerance for diversity, academic pressure), factors related to an individual's background (worldview, cultural values) and individual factors (age, gender, foreign language proficiency) (Berry, 1997; Sümer, 2009). The importance of individual factors (age, gender, education, motivation, personal background, etc.) is also stressed by Stefanenko (2000), who argued that individual and group factors (the latter include, among others, cultural similarities and differences, specifics of home and host countries' cultures, etc.) can significantly influence the duration of the adaptation process.

The fact that many international students experience psychological distress when finding themselves in a new environment makes students' adaptation processes to new living and learning conditions an important issue for analysis in many respects - psychological, pedagogical, cultural and academic. Research showed that the state of psychological distress and culture shock - a sense of disorientation and confusion students may feel when experiencing an unfamiliar way of life - is significantly and negatively related to both the psychological and sociocultural adaptation of newcomers (Presbitero, 2016). This fact brings up a question of how international students' adaptation can be made easier and more efficient. This paper aims at discussing one of the possible ways to lower psychological distress and to help international students adapt to the new conditions more easily, which is the development of their communication skills. In our opinion, the ability to communicate effectively with one's peers, teachers, colleagues, and a broader circle of people can make adaptation processes easier and stimulate students' integration into the new society through regular contact with the locals. 
To put the discussion about communication skills as a possible way to ease international students' adaptation into a broader theoretical context, we attempted to classify the existing approaches to international students' adaptation, examining different types (general living, academic, socio-cultural, personal-psychological and others) with a particular emphasis on the psychological and socio-cultural adaptation of students. It should be noted that we understand psychological adaptation in this paper following Ward and colleagues "affective responses including a sense of well-being and self-esteem, as well as physical well-being" (Ward, Bochner, \& Furnham, 2001), while socio-cultural adaptation hereinafter refers to "a set of appropriate socio-cultural skills that enable individuals to live successfully in an intercultural milieu" (ibid).

Let us note that in the current research, we will pay special attention to the adaptation processes of international journalism students in Russia - a group that has not been in the spotlight of academic research yet. The choice of this particular group was determined by the fact that journalism programs are to a large extent already aimed at developing students' communication skills through seminars, practical training, field work and internships in newsrooms. This background gives us an opportunity to see whether developed communication skills can make adaptation processes easier for international students and - consequently - whether any of the techniques used in journalism class can be implemented in work with students majoring in other subjects as well.

Finally, in this paper, we will hold to the definition of adaptation suggested by Castro (2003), who defined adaptation as "a development of cultural and social skills, sensibility to the beliefs, values and norms of the new culture and the acquisition of adequate communication skills for interacting effectively with the host culture". A small addition to this definition is that, in this paper, we will use terms the "communication skills" and "communication competence" interchangeably. Even though these notions are not identical, they both describe the ability to establish and support productive communication with other people.

\section{Method}

The primary method we used in this research into publications by both Russian and international scholars issued in the last twenty years centered around the following key problems: international students' adaptation processes in general, adaptation of particular groups of students, singled out by ethnic, cultural, gender, professional or any other factors, the role of communication skills in students' personal development and adaptation processes, and possible ways to ease adaptation processes for international students.

Although this paper has a relatively narrow focus, namely, the discussion of the role of communication skills in international journalism students' psychological and socio-cultural adaptation, we believe it is essential to create a theoretical model of what has already been covered in relation to international students' adaptation and to suggest our contribution to this discussion by offering a set of general and specific measures aimed at making adaptation for journalism students and students majoring in other disciplines easier, specifying the role of communication competences in this proces. 
Let us note that although in this paper we will focus primarily on psychological and socio-cultural adaptation of international students, we agree with Tseng (2002) that this group of students has to address different types of adaptation at the same time, including general living, academic, socio-cultural and personal-psychological types of adaptation. Therefore, we did not exclude these types of adaptation from our research scope either, arguing for a complex and multifaceted overview of this phenomenon.

\section{Results}

First, we determined that a significant cluster of research is devoted to the international students' adaptation process in general (Ward, 2001; Tseng, 2002; Castro, 2003; Berry, 1997, 2006; Sümer, 2009; Kulikova, 2007; Vitkovskaya \& Trotsyk, 2005; Abdina et al, 2015; Hajara, 2014, etc.), treating it as a psychological and cultural phenomenon and oftentimes examining a particular type of this phenomenon. For instance, Ward (2001) outlined the specifics of psychological and socio-cultural adaptation, arguing that each of these two types of adaptation is influenced by a different set of variables: psychological adaptation is influenced by personality traits, coping strategies and available social support, whereas socio-cultural adaptation is influenced by length of residence in the new culture, cultural knowledge, language ability and acculturation strategy.

Tseng (2002) paid special attention to the general living adaptation of international students in a new country, which includes adaptation to the local food, living environment, transportation, climate, financial and health care systems. We cannot but agree that many of these everyday phenomena may cause confusion among international students when they face them for the first time. In this case, general orientation upon arrival and introducing students to the everyday reality in Russia by the locals (specifically assigned university officials and/or peer students) can be very helpful, in our opinion.

Sümer (2009) studied academic adaptation, which includes proficiency in the language of a new country, knowledge about the local educational system, and effective learning skills. Sometimes academic adaptation is perceived as the most crucial type of adaptation and becomes the focus of attention in scholarly works (Halamandaris \& Power, 1999). Although studying factors contributing to successful academic performance is certainly an important task, we believe that this type of adaptation should not be considered a dominant one. One of international students' main goals is obviously to succeed in class. However, this goal can hardly be achieved without students' adaptation to the socio-cultural environment in which this class is conducted. Getting accustomed to a new system of values, beliefs, norms and regulations is what socio-cultural adaptation is about. Its role in achieving academic adaptation is significant. Without developed cultural and social competences, students will possibly experience difficulties in communication with their classmates, teachers and advisors and will not be able to comprehend what is going on in the class in the fullest sense. In regard to journalism students, for example, good knowledge of the values and norms of Russian society along with respecting (not necessarily sharing) these norms and values will help when covering stories in media outlets or working as a part of student groups on media products. Students 
will learn about the culture they live in and will be able to speak about this culture and communicate with people raised in it with tolerance, respect and full understanding of its specifics.

Personal-psychological adaptation has been in the spotlight in a number of research studies (Vasyakin et al, 2015; Yang et al, 2015; Berestneva, Marukhina, \& Shcherbakov, 2013; Kravtsov, 2008; Ivanova, 2001, etc.). Since many international students suffer from depression, isolation and homesickness when away from home and a familiar environment, their academic, socio-cultural, and general living adjustment can become even more complicated. Let us also note that all these types of adaptations, though rather general and typical to some extent for all international students, may differ in relation to a particular study major. International students coming abroad to study humanities or social sciences, for example, are expected to be involved into a whole range of communication activities. Starting from freshman year, journalism students, for instance, are taught how to conduct interviews, write reports about an event they have been to, visit presentations and round table discussions, use social media, and other skills. All these activities require constant communication with people, not necessarily the ones students already know. This fact can make adaptation processes more difficult and long-lasting, which raises a question about means of easing students' adaptation in Russia.

Research in the field of ethnopsychology, both domestic (Lebedeva, 1999; Stefanenko, 2000; Krysko \& Sarakuev, 2001; Baronin, 2000; Platonov, 2012) and international (Shweder, 1991; Kirkpatrick \& White, 1985; White, 1995; Despret, 2002; Turner, 2012), has emphasized the importance of successful psychological and socio-cultural adaptation for building harmonious relationships with representatives of cultures and ethnicities different from one's own. Scholars thus stressed that the role of psychological trainings, especially those aimed at revealing culture differences and showing ways to address them, can hardly be underestimated in regard to successful adaptation in a new country. Trainings may include, for example, cognitive (those providing information about host country and discussing difficulties in adaptation process in small groups) or attributive ones (those directed to learning how representatives of various nations and cultures interpret reasons for behavior and the results of activity) (Stefanenko, 2000; Wiseman et al, 2007; Kononova, 2012). Culture assimilators can be another efficient way to learn intercultural differences through introducing students to a variety of standpoints and opinions shared by people with different cultural backgrounds (Stefanenko, 2000; Kononova, 2012). As a result, students get to know the new culture better and learn how to communicate with the locals in a respectful and unbiased way.

Second, we examined research analyzing adaptation of particular groups of students in a new living and learning environment, specifically looking for information about journalism students. We revealed that many research studies aimed to study the specifics of international students' adaptation and focused primarily on general problems of adaptation and acculturation and/or covered experiences of particular universities in enhancing students' adaptation processes (see for example a paper by Vitkovskaya \& Trotsyk (2005) about the case of Peoples' Friendship University of Russia or a paper by Krivtsova (2011) about the adaptation of international students at Voronezh State Medical University). A large-scale sociological research study was carried out in 2009 at Udmurt State University (Izhevsk, Rus- 
sia). This research addressed academic and social adaptation of freshmen, without analyzing international students specifically. Interesting observations suggested in this research include signifying an important role of student academic groups, student organizations, scientific societies for students and students' academic advisors in helping students get accustomed to a new learning environment (Adaptatsiya studentov pervogo kursa..., 2009). The principal research method in this study was analyzing questionnaires filled out by students from different academic departments, including 17 journalism students. However, this study did not specify the difference in adaptation processes experienced by international and domestic journalism students. All in all, we found very few research studies focusing on a particular group of international students grouped together by majors, countries of origin or any other factors, unlike the number of those speaking about the adaptation of international students in general.

Third, we came across a substantial number of research studies discussing the role of communication skills in one's personal development and in the society in general. As Morreale et al (2000) articulate, developed communication competences are essential for a whole range of reasons, including an important role of communication in a person's development, career services, business enterprises, and, speaking more broadly, in the development of societal and political life and in inter-cultural understanding. The idea that communication competence and cultural competence are closely interrelated is supported by Wang (2011), who studied cultural codes and suggested that communication skills are indispensable for a culturally literate person, the one who "possesses both the language codes and contextual knowledge of a social environment" (Borden 1991). Dunas (2011) analyzed communication and communication competence through an anthropological approach. The development of students' communication skills in both theoretical and practical aspects were studied by Smirnova (2007) and Lyutova (2007), who also conducted one of the few research studies aimed at analyzing international journalism students' education process, though not focusing on their adaptation processes. Most of the researchers agree that communication competence can contribute to individuals' social adjustment and participation in satisfying interpersonal relationships. As Morreale et al (2000) note, youngsters with poor communication skills are sometimes viewed as less attractive by their peers and enjoy fewer friendships. In addition, the ability to communicate orally supports sound psychological development. In psychological terms, achieving self-actualization involves communication activities such as making contributions in groups, exerting influence over others, and using socially acceptable behavior (ibid).

In summary, we have to say, though, that despite the fact that the number of publications on communication skills in general is relatively large, we failed to find many research studies thoroughly outlining the role of communication skills in international students' adaptation processes, be it the group of international students in general or those who chose particular majors for their study abroad experience. One of the few publications on this topic is a research study by Westwood \& Barker (1990), who underlined that the achievement rates of the international students who participated in a peer-pairing program with the local students are in most cases higher, and their social adjustment is in most cases easier compared to those who did not take part in that program. This fact proves that communication 
practice plays an important role in both academic and psychological adaptation of international students in a new country.

Lastly, we tried to identify publications discussing possible ways to ease adaptation process for international students. Scholars more or less agree that communication with the locals (teachers, peers, advisers, employers, etc.) is an effective way to adapt to new living and learning conditions easier. Tran Ly Thi (2008) emphasized that there is a correlation between students' adaptation and the regularity of their interaction with the lecturers through face-to-face consultation, emails and discussions in class, which we admit to be important. Another way to help students adapt to a new environment is, according to Stefanenko (2000), Vasyakin et al (2015) and Nugmanova (2015), a series of psychological trainings aimed at developing students' adaptation skills, as well as their self-regulation resources, which also play an important role in adjustment to a new living environment or to a new group of people.

Keeping in mind a limited number of theoretical and empirical research studies on this topic, we decided to suggest a very rough classification of measures to help students adjust to a new living and learning environment. Since this research is aimed primarily at analyzing psychological and socio-cultural adaptation of international students, these measures are primarily focused on ways to overcome difficulties connected with these types of adaptation, although we believe that most of them can be used when dealing with other types of adaptation as well.

We argue that these measures can be divided into two big groups: general ones and specific ones. General ones can be used when dealing with all groups of international students no matter which major(s) they chose. This type of measures may include, but is not limited to, building contact between an international student and his/her academic advisor or/and student peers, including extracurricular activities and cultural events into students' schedule, providing psychological support and orientations to the students, organizing psychological trainings for students and much more. We believe that all these activities are extremely valuable and helpful for the international students' psychological and socio-cultural adaptation in a new country, especially when used together.

Talking more specifically, the role of academic advisors and student peers is clearly essential. Quite often, students do not know anyone when coming to a new country to live and study. Academic advisors, whose duties include providing educational guidance and assistance for students by planning schedules, recommending courses and determining appropriate education solutions, can be extremely helpful. Getting domestic students interested in contacting their international peers before or upon their arrival, and providing them informal support, orienting them in a new environment can be useful, too. International students become familiar with a new country and culture, and domestic students develop their cultural sensitivity and learn more about the culture from which their international peer comes.

Along with support from academic advisors and student peers, international students should be provided with general and special orientations. In this case, teaching students about the health care system, transport, climate, food in the new country, and other topics is the purpose of a general orientation upon and/or before arrival, while teaching students about values, beliefs, norms, and regulations in a new country and showing them how to behave in a professional environment 
(journalists' ethics and an the vision of what is morally acceptable or not - like revealing confidential sources, for example, can vary in different countries) should be covered in a special orientation.

While orientations are usually organized a few times only, psychological support should be available to the international students on a permanent basis. Be it an academic advisor, whose list of responsibilities includes, besides academic work, psychological counseling, or a separate service at universities, this type of work is extremely important in regard to helping international students get accustomed to new life realities. Additionally, Ivanova (2001) notes that international students should be taught how to use self-regulation tools, especially at the very beginning of their study period, when they are in a "state of shock" (ibid) and not familiar with the learning and living environment. Last but not least are extracurricular activities aimed at bringing students together and encouraging them to learn from each other. Examples of such activities may be various joint projects, excursions, trips, celebrations, and others.

Now let us examine more closely the specific measures that can be used to make the adaptation processes of international students easier. This type of measure, in our opinion, is oriented towards a particular group of students, in our case journalism students. First, let us note that one of the prerequisites for applicants, both domestic and international, wishing to study journalism are developed communication skills, which are usually tested at an oral entrance examination. These skills seem to be indispensable, since journalist's work can hardly be imagined without communication with people, both oral and written, which is why the selection committee normally takes these skills into account when making admission decisions. However, international students coming to Russia to study journalism oftentimes have less developed communication skills than domestic students, first because of lack of language proficiency, and second because they do not feel comfortable in a new environment yet. We believe that developing their communication skills can be useful both for preparing them for their future profession and for easing their adaptation processes. Let us take a look at possible ways to strengthen international students' communication competence now, keeping in mind that first, we are focused on journalism students primarily, second, that many of these methods can be used in work with international students majoring in other subjects too, and third, that the purpose of communication skill development is a complex one (psychological and socio-cultural adaptation, academic adaptation, preparation for the professional career in journalism, self-actualization through communication, etc.).

To start, journalism programs at Russian universities, like in many international universities, are focused on developing an array of different skills and abilities: effective oral, written and visual communication abilities, effective research, interview and information gathering abilities, and others. Vartanova \& Lukina (2014) examined different sets of skills that Russian journalists should possess in order to be in demand on the market today. They emphasized that communication skills are ranked rather highly today, meaning by communication skills an ability to interact with the audience, participate in planning social events (discussions, debates and others), get in touch with different sources when working on a story, and other aspects. (Vartanova \& Lukina, 2014). It seems clear that communications skills are one of the most important sets of skills every good journalist should possess and a 
prerequisite for future success in professional work. Since journalists primarily get their information from people, they should be able to conduct interviews and cover personal stories, ask relevant questions, listen carefully and simply have a pleasing personality so people would be willing to talk to them. In addition, journalists should have the ability to build contacts and have friends from different walks of life who can serve as a source when needed. All things considered, developed communication skills are essential for future journalists.

That is why an important component of journalism education along with theoretical courses are various practical assignments, such as work on joint projects, meeting with journalists and media practitioners, participation in seminars, workshops, trainings, internships in newsrooms, field trips to media outlets and handson experience of producing newspapers, TV and radio programs, and multimedia content for websites in class, among others. Communication with classmates, teachers, viewers, interviewees, journalists and media owners is an inseparable part of all these activities. Starting from freshman year, students learn to be open-minded, curious, disciplined, stress-resistant persons able to build effective communication with people belonging to different social, cultural, professional, and ethnic groups. However, while taking part in all those activities, students not only learn how to become good journalists but also begin to understand themselves better and get accustomed to their new professional environment.

For international students, practical assignments can be of extra value. While participating in seminars, trainings, role games in class and internships, students make new friends, learn about the new culture and society (what is appropriate and what is not, what roles men and women perform in the society, etc.), gradually get accustomed to a new reality, and find their own place in the society that is new to them. Joint projects, which require work in pairs or small groups (like producing an edition of a student newspaper or working on a TV show in a studio) are particularly helpful. Having found themselves in a completely new living and learning environment, struggling with academic and general living challenges, students need people they can talk to in case of problems or questions. Academic advisors and psychological counselors can be of much help, but they cannot replace classmates and people of the same age and interests. That is why practical assignments can play tbe role of "integrating factor", bringing domestic and international students closer to each other and encouraging them to work together and learn from each other. Moreover, this "integrating factor" can later serve as a contribution to the general policy of integration (Gladkova, 2012, 2015), which is exceedingly vital in a multicultural, multiethnic and multilinguistic Russian society.

By participation in seminars, trainings and other types of practical learning activities, international students go beyond class routine and build contacts with different people, like visiting scholars from abroad or media practitioners. These contacts may follow up later in an internship, curriculum or optional practical training, or even a temporary job. Along with the professional development, students acquire knowledge of the media sphere, roles and mission of journalists in a given society, learn how to overcome challenges in professional work and establish effective communication with people. This process, in turn, contributes to further psychological and socio-cultural adaptation of students. They become more confident when outside the classroom and away from people they know well (classmates, 
teachers, academic advisors, etc.), they learn the importance of productive communication (in order to acquire information, perform a task successfully, get accepted for an internship, etc.) and start feeling less lonely and depressed when away from home. Students also become familiar with the set of norms, moral and ethical issues, regulations and laws that exist in the country where they study, which contributes a lot to their socio-cultural adjustment. We believe that though theoretical preparation (reading books and instructions, participating in orientations, talking to academic advisors and international students who studied in Russia before) can be helpful, nothing can substitute real communication with the locals in regard to learning about the society.

We are also convinced that an effective tool for stimulating socio-cultural adaptation of international students and developing their communication competence is a course (both theoretical and practical ones) on intercultural communication. For journalism students, whose professional roles and responsibilities include communication with people from different cultural backgrounds, intercultural communication is an indispensable part of the learning process. In this case, we mean not only students majoring in foreign or international journalism but all other majors as well. In an era of globalization, which, as Vartanova (2005) mentions, is a complex phenomenon involving communication, media, business, culture spheres, and intercultural communication, competence is becoming more and more important. Having gained a better understanding of cultural differences and ways to establish efficient communication with people different from themselves, students develop professional competence to build relations easily when working on a media product in all journalism fields - broadcasting, print media, Internet, interviewing people, gathering opinions, and others. In addition, they start understanding that all cultures are equally important, and neither of them should be considered superior, which, in turn, has more to do with developing individual values and characteristics of the students (Gladkova, 2013).

In many Russian universities, including Lomonosov Moscow State University's Journalism Faculty, intercultural communication has been included in the list of required courses for both domestic and international students. This course focuses not only on teaching theories of intercultural communication, approaches to different cultures, their peculiarities and their differences. Its goal is to teach students how to establish productive communication with people belonging to diverse cultural, ethnic, linguistic, religious groups through numerous practice-oriented tasks and subsequently develop their communication skills and make them feel more comfortable when getting in touch with people around them.

The list of these tasks includes pair and team work on a project, usually related to students' specialization in one of the journalism fields - broadcasting, photojournalism, media economics, fashion journalism, and others. An important part of this working-together scheme is that students are usually asked to work in pairs or small groups with people from different cultures. Team and/or pair work usually starts with a simple task, such as making a short dialogue, asking a team partner about his/her family, hobbies, recent travels or favorite movies and later develops to a larger task - spending a few hours together working on a project. Students choose topics and methods themselves after consultation with one of the teachers. Journalism projects may include, but are not limited to, conducting a series of in- 
terviews on a topic of current interest, writing article for a student newspaper or for a blog, or shooting video, among others. An outcome of each project is presented to the rest of the class and openly discussed.

The tasks that include team and pair work have proved to be rather efficient in many senses. First, they help students get to know their classmates better. It is not a secret that quite often international students in Russia do not feel themselves part of the student community, be it due to their low language proficiency or lack of opportunities for integration or cultural specifics that prevent them from expressing their emotions and needs in public. Projects aimed at bringing people together, even for a short time, can play the role of such integration factors. Although sometimes cases of non-willingness to establish contacts with their classmates belonging to a different culture may appear, for both domestic and international students, the majority of them are usually satisfied with the results of their team work.

Another creative technique is asking students to produce short essays on a topic related to cultural differences. The topics of such essays are usually thoughtprovoking and meant to stimulate discussion about the way different cultures perceive the same things, like family relationships, marriage, the role of women in the society, and others. It is always very interesting to see how students perceive their own cultures through creative writing as well as discuss essays all together in class. Not surprisingly, many students have stereotypes regarding other cultures and people living abroad, so this task is aimed at both breaking stereotypes and providing students an opportunity to re-consider their own culture, its specifics and peculiarities.

What we consider even more important than successful completion of tasks in this course is that students start getting together with their international peers more often: greeting them in the corridor, asking informal questions, and sitting together in class. We may conclude thus that pair and team work as well as discussion of creative writings contribute to students' understanding of intercultural communication as an efficient tool to build contacts with people, something journalism cannot be imagined without. Moreover, it teaches them that all men are created equal, no culture should trump the others, and prejudices against other cultures are very often far from being true. Finally, international students become more comfortable in class, get used to the society, make new friends and gradually adapt to the new country both psychologically and culturally.

\section{Conclusion}

The research demonstrated a significant difference in the number of studies examining adaptation (general living, psychological, socio-cultural, etc.) in general, without regard to specific characteristics of the audience, and those describing adaptation of a particular group of people (in our case, international journalism students). A similar situation was observed when comparing a profound number of research studies emphasizing an important role of communication skills in general, and those speaking about communication skills in the adaptation processes of particular groups of people. In our view, there is certainly a need for more detailed, narrowly focused research discussing the specifics of adaptation of different groups of people to a new living and learning environment because we believe different 
people tend to adapt to new conditions in different ways, and research outlining the role of communication competences in their adaptation process.

Having discussed the role of communication skills in psychological and sociocultural adaptation of international journalism students, we may conclude that communication competence is certainly an important factor in both stimulating their adaptation process and familiarizing students with cultural codes and the realities of a new society. As we have noted, most adaptation measures can be used in work with all international students no matter which major(s) they chose (like academic advising, psychological counseling, peer counseling, orientations, extracurricular activities, psychological trainings, etc.). Communication skill development, which is attributed in this paper to a category of specific measures, can be basically considered a part of general measures, since all international students need to have communication competence to build relationships in a new society, make friends, understand the culture better and express themselves. We believe, though, that for journalism students, communication skills are particularly essential. Otherwise, their professional work, which presupposes communication with many different people every day, would be impossible.

The list of possible ways to develop communication skills is certainly broader than the one we presented in this research (including joint projects, essays, course of intercultural communication, team work, field trips, etc.) and deserves a separate large-scale study. In this paper, we were attempting to show that while these measures are widely used in journalism education, they can be successfully implemented in work with students majoring in other subjects too. The outcomes of this practice make it easier to adapt to the new society, its culture, everyday realities, living and learning standards, increase self-confidence in international students, including their ability and willingness to communicate with others, and finally improve their ability to address the challenges each international student faces in a new country.

\section{Limitations}

Since this research is purely theoretical and does not involve any empirical data analysis, the conclusions outlined earlier are generally based on the collection of academic works we had access to though various domestic and international databases. We are not ready to claim that the number of publications on adaptation in general, adaptation of particular groups of people, measures to ease adaptation process, or the role of communication skills in adaptation processes is limited to those included into this paper. The number of such publications by Russian and international authors is certainly much larger and deserves another large-scale study.

\section{References}

Abdina, A.K., Abdildina, H.S., Gappasova, A.G., Kakimzhanova, M.K., Valerievich, D., \& Sadykova, T.M. (2015). Foreign students' social adaptation to the education environment of a higher educational institution: By the example of S. Seifullin Kazakh Agro Technical University. Mediterranean Journal of Social Sciences, 6(5), 184-194. doi: 5901/mjss.2015. v6n5p184 
Adaptatsiya studentov pervogo kursa Udmurtskogo gosudarstvennogo universiteta $k$ uchebnoi $i$ vneuchebnoi deyatelnosti [Adaptation of the first-year students of Udmurt State University to academic and non-academic activities]. (2009). Retrieved from http://uvvr.udsu.ru/ docs/2009_adaptaciya_1kurs

Arefyev, A., \& Sheregi, F. (2014). Inostrannye stydenty v rossiskikh vuzakh [International students in Russian universities]. Moscow: Tsentr sotsiologicheskikh issledovanii.

Baronin, A.S. (2000). Etnicheskaya psikhologiya [Ethnopsychology]. Kiev, Ukraine.

Berestneva, O.G., Marukhina, O.V., \& Shcherbakov, D.O. (2013). Problema adaptatsii inostrannykh studentov kak problema adaptatsii subjekta deyatelnosti k izmenennym usloviyam [Adaptation problem of foreign students as a problem of adaptation activities subject to various conditions]. Sovremennye problemy nauki i obrazovaniya [Contemporary Issues in Sceince and Education], 4, 340-350. Retrieved from http://www.science-education.ru/ru/ article/view?id=9985

Berry, J.W. (1997). Immigration, acculturation, and adaptation. Applied Psychology, 46, 5-68.

Berry, J.W. (2006). Stress perspectives on acculturation. In D. L. Sam, \& J. W. Berry (Eds.), The Cambridge handbook of acculturation psychology. New York, NY: Cambridge University Press. doi: 10.1017/CBO9780511489891.007

Borden, G. (1991). Cultural orientation: An approach to understanding intercultural communication. Englewood Cliffs, NJ: Prentice Hall.

Castro, V.S. (2003). Acculturation and psychological adaptation. Westport, CT: Greenwood Press.

Despret, V. (2002). Our emotional makeup: Ethnopsychology and selfhood. New York: Other Press.

Dunas, D. (2011). Towards an anthropological theory of media communication research. World of Media. Yearbook of Russian Media and Journalism Studies, 71-81. Retrieved from http:// worldofmedia.ru

Gladkova, A. (2013). Cultural pluralism in Russian press: Challenges and prospects of development. World of Media. Yearbook of Russian Media and Journalism Studies, 325-333. Retrieved from http://worldofmedia.ru

Gladkova, A. (2013). The role of television in cultivating the values of pluralism and cultural diversity in children. Psychology in Russia: State of the Art, 6(1), 138-143. doi:10.11621/ pir.2013.0113

Gladkova, A. (2015). Linguistic and cultural diversity in Russian cyberspace: examining four ethnic groups online. Journal of Multicultural Discourses, 10(1), 49-66. doi: 10.1080/17447143. 2015.1011657

Hajara, M. (2014). An analysis of acculturative stress, sociocultural adaptation, and satisfaction among international students at a non-metropolitan university (Doctoral dissertation). Retrieved from http://digitalcommons.wku.edu/diss/63

Halamandaris, K.F., \& Power, K.G. (1999). Individual differences, social support, and coping with the examination stress: a study of the psychosocial and academic adjustment of first year home students. Personality and Individual Differences, 26, 665-685. doi: 10.1016/ S0191-8869(98)00172-X

Ivanova, M. (2001). Sotsialno-psikhologicheskaya adaptatsiya inostrannukh studentov $k$ vyshei shkole Rossii [Social and psychological adaptation of international students to Russian higher school] (Doctoral dissertation). Retrieved from http://www.dissercat.com/content/ sotsialno-psikhologicheskaya-adaptatsiya-inostrannykh-studentov-k-vysshei-shkole-rossii

Kirkpatrick, J., \& White, G.M. (1985). Exploring ethnopsychologies. In White, G. M., \& Kirkpatrick, J. (Eds), Person, self, and experience: Exploring Pacific ethnopsychologies. Berkley: University of California Press. 
Kononova, S.N. (2012). Soderzhanie formirovaniya etnotolerantnykh otnoshenii u buduschikh spetsialistov v vuze [Forming of ethnotolerant relations of future specialists in the institutes of higher education]. Chelovecheskiy kapital [Human Capital], 1(37), 122-123.

Kravtsov, A.V. (2008). Sotsialno-psikhologicheskaya adaptatsiya inostrannykh studentov $k$ vyshei shkole Rossii [Social and psychological adaptation of international students to the Russian institutions of higher education] (Doctoral dissertation). Retrieved from http://www.dslib. net/soc-psixologia/kravcov-socialno-psihologicheskaja-adaptacija-inostrannyh-studentov-k-vysshej-shkole-rossii.html

Krivtsova, I.O. (2011). Sotsiokulturnaya adaptatsiya inostrannykh studentov k obrazovatelnoi srede rossiiskogo vuza (na primere Voronezhskoi gosudarstvennoi meditsinskoi akademii imeni N.N. Burdenko [Sociocultural adaptation of international students to the academic environment of a Russian university (exemplified by Voronezh State Medical Academy named after N.N. Burdenko]. Fundamentalnye issledovaniya [Fundamental Research], 8, $125-140$.

Kulikova, O. (2007). Problema adaptatsii inostrannykh studentov $v$ protsesse obucheniya $v$ rossiskom vuze [Problem of international students' adaptation to studying at a Russian university]. Retrieved from http://jurnal.org/articles/2007/psih4.html

Lebedeva, N. (1999). Vvedenie v etnicheskuyu i kross-kulturnuyu psikhologiu [Introduction to ethno- and cross-cultural psychology]. Moscow.

Lyutova, O. (2007). Obuchenie inostrannukh studentov-zhurnalistov glagolam rechemyslitelnoi deyatelnosti [Teaching international journalism students verbs expressing verbal and cogitative activity]. Fundamentalnye issledovaniya [Fundamental Research], 10, 135-145.

Malykhin, M. (2015). Rossiiskie vuzy uvelichat priem inostrannykh studentov [Russian universities will increase the enrollment of international students]. Retrieved from http://www. vedomosti.ru/management/articles/2015/02/19/student-stupenka-k-rejtingu

Morreale, S.P., Osborn, M.M., \& Pearson, J.C. (2000). Why communication is important: a rationale for the centrality of the study of communication. Journal of the Association for Communication Administration, 29, 1-25.

Nugmanova, D.R. (2015). Activation of personal and subjective self-regulation resources in the context of social-psychological training. Review of European Studies, 7(5), 1-20. doi: $10.5539 /$ res.v7n5p237

Platonov, Yu.P. (2012). Etnopsikhologiya [Ethnopsychology]. Moscow: Academia.

Presbitero, A. (2016). Culture shock and reverse culture shock: The moderating role of cultural intelligence in international students' adaptation. International Journal of Intercultural Relations, 53, 28-38. doi: 10.1016/j.ijintrel.2016.05.004

Shweder, R. (1991). Thinking through cultures: expeditions in cultural psychology. Cambridge: Harvard University Press.

Smirnova, E. (2007). Rol formirovaniya kommunikativnukh umenii v professionalnoi podgotovke buduschikh spetsialistov [Role of communication skills in professional training of future specialists]. Herzen State Pedagogical University Bulletin, 30(8), 89-95.

Stefanenko, T. (2000). Etnopsikhologiya [Ethnopsychology]. Moscow: Aspekt Press.

Sümer, S. (2009). International students' psychological and sociocultural adaptation in the United States (Doctoral dissertation). Retrieved from https://pdfs.semanticscholar.org/aa5c/eff0932aec6a36626bcd16c1c90813a03c90.pdf

Tran, L.T. (2008). Mutual adaptation of international students and academics for the sustainable development of international education. Paper presented at EDU-COM 2008 International Conference. Retrieved from http://ro.ecu.edu.au/cgi/viewcontent.cgi?article=1057\&contex $\mathrm{t}=$ ceducom 
Tseng, W. (2002). International students' strategies for well-being. College Student Journal, 4, 591-597.

Turner, R. (2012). The need for systematic ethnopsychology: The ontological status of mentalistic terminology. Anthropological Theory, 12, 29-42. doi: 10.1177/1463499612436462

Vartanova, E. (2005). Globalizatsiya SMI i mass-media Rossii [Globalization of Russian mass media]. Vestnik Moskovskogo Universiteta. Seriya 10, Zhurnalistika [Moscow University Journalism Bulletin], 4, 9-25.

Vartanova, E., \& Lukina, M. (2014). New competences for future journalists: Russian journalism education executives evaluate industrial demand. World of Media. Yearbook of Russian Media and Journalism Studies, 209-233. Retrieved from http://worldofmedia.ru

Vitkovskaya, M., \& Trotsyk, I. (2005). Adaptatsiya inostrannykh studentov k usloviyam zhizni i ucheby v Rossii (na primere RUDN) [International students' adaptation of living and studying condition in Russia (case of RUDN university)]. Vestnik RUDN [Russian University of People's Friendship Bulletin], 67, 267-283.

Wang, J. (2007). Communication and cultural competence: The acquisition of cultural knowledge and behavior. Online Readings in Psychology and Culture, 7(1). doi: 10.9707/23070919.1064

Ward, C. (2001). The ABCs of acculturation. In D. Matsumoto (Ed.), The Handbook of culture and psychology. New York, NY: Oxford University Press.

Ward, C., Bochner, S., \& Furnham, A. (2001). The psychology of culture shock. London: Routledge.

Westwood, M. J., \& Barker, M. (1990). Academic achievement and social adaptation among international students: a comparison groups study of the peer-pairing program. International Journal of Intercultural Relations, 14(2), 251-263. doi:10.1016/0147-1767(90)90008-K

White, G.M. (1995). Ethnopsychology. In Schwartz, T., White, G.M., \& Lutz, C.A. (Eds.), New directions in psychological anthropology. New York: Cambridge University Press.

Wiseman, D.G., Hunt, G.H., Zhukov, V.I., \& Mardahaev, L.V. (2007). Teaching at the university level: Cross-cultural perspectives from the United States and Russia. Springfield, IL: Charles C. Thomas Publishers Ltd.

Yang, Z., Tang, X., Duan, W., \& Zhang, Y. (2015). Expressive writing promotes self-reported physical, social and psychological health among Chinese undergraduates. International Journal of Psychology, 50(2), 128-134. doi:10.1002/ijop.12081

Original manuscript received June 27, 2016 Revised manuscript accepted April 05, 2017

First published online November 30, 2017 